\title{
PROFICIENCY OF FOREIGN LANGUAGES : A STUDY OF THE APPROVED TOURIST GUIDES OF AURANGABAD REGION
}

\author{
Madhuri T. Sawant* and Rajesh N. Ragde**
}

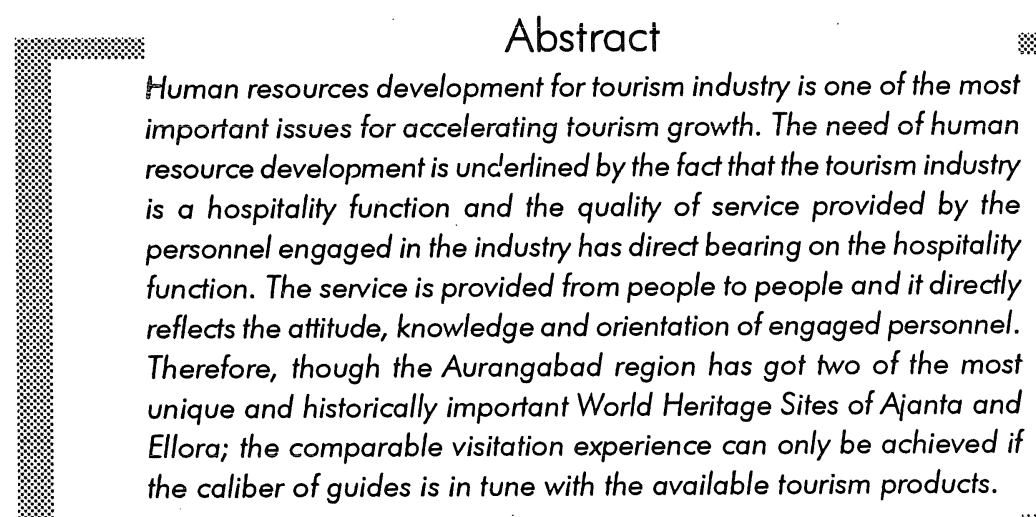

* UGC JRF, Dr. Babasaheb Ambedkar Marathwada University, Aurangabad.

* Sr. Lecturer, Department of Tourism Administration, Dr. Babasaheb Ambedkar Marathwada University, Aurangabad. E-mail : drrajeshragde@rediffmail.com 
The research paper examines the service standards and proficiency in the Foreign Languages of tourist guides available in the Aurangabad region which is still not up to the mark. The shortcoming generally lies in training. Most of the tourist guides engaged in tourism business do not have proficiency in foreign languages, resulting in lack of appreciation of their role and responsibilities. It is well known that people engaged in the tourism industries do not understand the significance of 'service' and the long term benefits it can bring in to their clientele rate.

\section{Introduction}

The Aurangabad region has a rich cultural and historical heritage; and to convert it into popular tourist product, it is important to have service oriented personnel employed in the tourism industry. This will help in the preservation of monuments and environment since these personnel can bring in the awareness about conservation and preservation, in the minds of tourists and the local population.

The Phase 1 of the Ajanta Ellora Conservation and Development Project financed by Japan Bank of International Co-operation has been completed in the region. The Phase 2 of the Ajanta Ellora Conservation and Development Project will provide a big boost to the tourist traffic that are to be provided orientation in the planned tourist complexes at Ajanta and Ellora. Therefore, the fourist complexes are expected to be hubs of activity and will play an important role in enhancing the overall visitation experience of the tourists. Hence the monuments as well as the tourist complexes will require increasing number of trained guides and service personnel to maintain the quality of visitation experience with increased traffic.

\section{Study Objectives}

The tourist guides come in direct contact with the tourists and their performance has direct bearing on the visitation experience of the tourist. Therefore, guides service was considered as a priority area for facility development and given the first preference for the study analysis.

The following are the objectives of the study;

1) To study the existing level of tourist guide services in the Aurangabad region.

2) To examine the existing guide training programmes for tourist guides. 
3) To study the requirement of training courses in foreign languages for tourist guides.

\section{Types of Tourist Guides in India}

Approved tourist guides or authorized tourist guides in India are classified into two categories as described below:

1) Tourist Guide (General) : Nomination, qualification and authorization of these approved tourist guides is done by the Regional Tourist Office, Government of India (GOITO), such as in Aurangabad and Bombay. Each Regional Tourist Office is also incharge of maintaining the role of the guides as well as dealing with assignment of guides according to the day-to-day requests made by travel agencies, tour operators, tour parties and hotels in the region.

2) On-site Guide (Archaeological Sites) : Archaeological Survey of India (ASI) is incharge of selection, qualification and nomination of on-site- guides. These guides are of the nature that their work place is defined to the specific archaeological sites and the number is quite limited.

Besides these two types of guides mentioned above, there exist a number of self appointed guides (illegal guides) in and around the world famous monuments such as Taj Mahal, Fatehpur Sikri, Qutub Minar, Hampi etc. They are a nuisance for visitors because they are often persistently hanging around the tourists and do not hesitate in misguiding visitors, whenever the situation suits them. It, however, is hoped that the Central and State governments would take necessary measures to eliminate them because they can become a hindrance to healthy growth of tourism at Ajanta / Ellora in the future.

\section{Training Programmes for Regional Tourist Guides}

Guide training is inevitable for the growth and development of tourism. However there are no regular guide training courses conducted by the Government of India, Tourist Office, Aurangabad or any other Government agency and there exists no exclusive training facility for the Regional Tourist Guides in the Aurangabad region.

In the recent past, the XI Regional Guide training course was conducted by the Government of India, Tourist Office in the year 1996 at Aurangabad. In this course, 13 candidates were trained who qualified as Regional Tourist Guides. 
Again after a gap of nine years, the XII Regional Tourist guide training course was conducted by the Government of India, Tourist Office, Aurangabad; in which, 23 candidates qualified as Regional Tourist Guides.

The Government of India, Tourist Office is an implementation body for conducting the Regional tourist guide training courses. The criteria for selection and training of the Regional Tourist Guide is as follows:

\section{Educational qualifications}

a) Minimum : Graduate from a recognized University OR Three years degree holder in Tourism / Hospitality from a recognized University / Institute OR Diploma in Archaeology from the Institute of Archaeology under the Archaeological Survey of India, New Delhi or from any other recognized institutions / University.

b) Fluency in English language is essential.

c) Candidates proficient in any foreign language other than English and having sound knowledge of History and Culture will be given preference. They should have completed at least a six months regular course in the foreign language from a recognized University / approved institution embassy or consulate or their cultural center.

2. Age limit: The applicant shall be between the age of $20-65$ years on the date of the first advertisement appearing in the media for selection of guides.

The applications received are screened by a specially constituted committee and the eligible candidates have to appear for a written test, which confines to the following subjects:

i. Knowledge of monuments around the area : 50 marks.

ii History

: 50 marks.

iii General Knowledge

: 100 marks.

On the basis of the marks obtained in the entrance written test, the final selection is made through an interview.

\section{Actual Training}

The selected candidates have to make a payment of Rs. 2000/-towards the course fee, which excludes the practical training outside Aurangabad. 
The course is of 16 weeks duration with six weeks classroom teaching and 10 weeks practical training for which a minimum attendance of $80 \%$ is essential and on the completion of the training course, a written examination of 100 marks is held consisting of the entire syllabus. It is necessary for the guide trainee to secure minimum $40 \%$ marks to qualify for the Viva - Voce where the guiding skills, knowledge of the monument, fluency of language is tested. The successful candidates are then placed on the list of approved Tourist Guides maintained by the Department of Tourism, Government of India who are permitted to accept assignments and guide fees according to the prescribed fee and as per rules laid down by the Government of India from time to time.

\section{Present Status of Approved Tourist Guides in Aurangabad Region}

At present there are 67 approved tourist guides in the Aurangabad region, of whom 5 are not available because they have been engaged in other duties and/ or moved out of the region. Therefore effectively only 62 guides are available in the entire region. All these 62 guides can speak Hindi and English, and some guides speak one or more than one foreign languages also. Table 1 shows the number of the qualified guides in spoken languages.

Table 1 : Number of Guides in Aurangabad.

\begin{tabular}{|ll|}
\hline \multicolumn{1}{c|}{ Languages } & Nos. \\
\hline Hindi / English including foreign language speaking guides & 67 \\
\hline Japanese & 18 \\
\hline French & 10 \\
\hline Spanish & 09 \\
\hline Italian & 03 \\
\hline German & 07 \\
\hline
\end{tabular}

Source : GOITO, Aurangabad Approved Tourist Guide List

From Table 1 above, it is obvious that the languages spoken by guides are very limited as far as the world famous tourism destination of Ajanta and Ellora are concerned. The figures regarding the foreign language spoken by the guides given in the table, are as per the approved tourist guide list of GOITO, Aurangabad. The actual number of foreign language speaking guides is totally different. According to a survey taken for the study of 67 guides there are 13 
Japanese, 06 French, 07 Spanish, 03 Italian and 03 German language speaking guides.

Table 2 : Tourist Arrivals in Ajanta and Ellora.

\begin{tabular}{|c|c|c|c|c|}
\hline \multirow{2}{*}{ Year } & \multicolumn{2}{|c|}{ Ajanta } & \multicolumn{2}{c|}{ Ellora } \\
\cline { 2 - 5 } & Indian & Foreign & Indian & Foreign \\
\hline 2000 & 297957 & 5722 & 588456 & 38602 \\
\hline 2001 & 287732 & 18738 & 474632 & 13008 \\
\hline 2002 & 270536 & 14988 & 387777 & 9710 \\
\hline 2003 & 281670 & 20663 & 421891 & 12361 \\
\hline 2004 & 271442 & 26594 & 374640 & 15728 \\
\hline 2005 & 261255 & 28664 & 327331 & 14526 \\
\hline 2006 & 206846 & 23036 & 230227 & 11088 \\
\hline
\end{tabular}

Source : ASI, Aurangabad Circle.

Table 2 shows that there is a variation in the domestic tourist arrivals but, on an average the tourist flow appears to be constant whereas the foreign tourist arrivals show that in the year 2000 there were 5722 number of foreign tourist which is growing year after year except in the year 2002 which saw a decline in the foreign tourist arrivals. In the present situation for a number of 23036 foreign tourists the region has just 47 foreign language speaking guides which is very insignificant. The ratio of the foreign language guides to the foreign tourists arrivals comes to $1: 490$. Also, if we look at the trend of the foreign tourist arrivals, the number of languages is to be increased according to the target market countries identified in the marketing strategy. In addition, the current international tourist inflow trend e.g. from countries like China, Korea, Netherlands and Japan of which the numbers of tourist are steadily increasing, need to be supported with more number of qualified guides.

\section{Training Institutes of Foreign Languages in Aurangabad}

Aurangabad is also an important educational center in the country. The Dr. Babasaheb Ambedkar Marathwada University, Aurangabad has over 250 
affiliated colleges in the Marathwada region in which, 78 colleges are in the city of Aurangabad. The University also has a Foreign Languages Department which is the first department in the entire region. The department offers Proficiency Certificate Course, Diploma, Advance Diploma courses in German, French and Russian languages. There are three other private institutes which offer the German and Japanese language proficiency test which are in four levels short term courses. These are namely, Engle Institute of Foreign Languages, Trillion Info Tech Pvt. Ltd. affiliated with the Japan Foundation, Tokyo and Max Muller, Pune. Besides the limited number of available languages in which at present the guides are trained, there also exists shortage in the overall number of guides. This is very obvious on the peak days and weekends in the tourist high season.

\section{Conclusion}

Since the international tourists are considered as guests to the nation / state, they must be received and treated in a warm, pleasant and proper manner. The major findings are:

i) The existing level of the tourist guides in the region is not up to the mark. The tourist guides seem to function to a certain level in terms of sightseeing interpretation. There are other aspects which must also be looked into such as level of the foreign languages, knowledge of the monuments, mind set for hospitality and manner / attitude to interact with tourists.

ii) The frequency of the training programme for the tourist guides is about ten years. The ministry of Tourism does not take any initiative for the training of new guides; already there is an increase in the tourist arrivals in the region. The existing training programmes do not have any foreign language in their curriculum.

iii) There is scope for training the existing tourist guides in terms of proficiency in foreign languages as the ratio of guides to foreign tourist is just $1: 490$.

Overall education and training to provide accurate historical / cultural perspective is quite important; both for conservation of resources and for tourism use of historical resources. The service provided by well trained history and cultural conscious tourist guides and monument staff will provide a good image of the region as well as of the country to the domestic and foreign visitors, respectively. Demand for trained tourism personnel who are capable of providing quality service will increase not only for tourist complexes in the Ajanta and Ellora region; but also, in private enterprises such as hotels, restaurants, tour operators and transportation companies for the success of their tourism business. 
In this situation, it is required to provide necessary training infrastructure system for the humian resource development for guide services as well as of the personnel relating to tourism in the region.

\section{References}

1. Japan Bank for International Cooperation (2002) Guidelines for Confirmation of Environmental and Social Consideration.

2. Maharashtra Tourism Development Corporation (2002-2003) AEDP First Phase Report.

3. Maharashtra Tourism Development Corporation Tourism Development Plan Vol. 2. 